Article

\title{
Invasive Alien Plants and Invasion Risk Assessment on Pingtan Island
}

\author{
Minxian Luo ${ }^{1}$, Lifang Xiao ${ }^{1}$, Xuhui Chen ${ }^{1}$, Kaiqin Lin ${ }^{2}$, Bao Liu $\left.{ }^{1}{ }^{(}\right)$, Zongming He ${ }^{1}$, Jinfu Liu ${ }^{1}$ \\ and Shiqun Zheng ${ }^{1, *}$ \\ 1 College of Forestry, Fujian Agriculture and Forestry University, Fuzhou 350002, China; \\ 3200422048@fafu.edu.cn (M.L.); 3190422041@fafu.edu.cn (L.X.); 3200422019@fafu.edu.cn (X.C.); \\ liubao@m.fafu.edu.cn (B.L.); 000q131042@fafu.edu.cn (Z.H.); fjljf@fafu.edu.cn (J.L.) \\ 2 Pingtan Comprehensive Experimental Zone Natural Resources and Ecological Environment Bureau, \\ Fuzhou 350400, China; L0330kq@163.com \\ * Correspondence: fjzsq@126.com
}

Citation: Luo, M.; Xiao, L.; Chen, X.; Lin, K.; Liu, B.; He, Z.; Liu, J.; Zheng, $\mathrm{S}$. Invasive Alien Plants and Invasion Risk Assessment on Pingtan Island. Sustainability 2022, 14, 923. https:// doi.org/10.3390/su14020923

Received: 22 November 2021 Accepted: 22 December 2021 Published: 14 January 2022

Publisher's Note: MDPI stays neutral with regard to jurisdictional claims in published maps and institutional affiliations.

Copyright: (C) 2022 by the authors. Licensee MDPI, Basel, Switzerland. This article is an open access article distributed under the terms and conditions of the Creative Commons Attribution (CC BY) license (https:// creativecommons.org/licenses/by/ $4.0 /)$.

\begin{abstract}
Pingtan Island is the largest island in Fujian Province and the fifth largest island in China. The invasion of a large number of alien plants has had a profound impact on the local ecological environment. Because the harm caused by alien invasive plants varies greatly between different ecosystems and even in different habitats, the risk assessment index system suitable for one region may not be suitable for other regions. Therefore, it is necessary to establish a risk assessment index system for invasive alien plants on Pingtan Island. Alien plant communities in different habitats were studied by means of quadrat investigation and professional literature review. Some invasive alien species were selected and compiled into a list of invasive alien plants on Pingtan Island, and their species composition, origin, flora, life forms, and habitats were statistically grouped. There were 104 species in 80 genera and 37 families of alien invasive plants. Asteraceae, Fabaceae, Amaranthaceae, and Poaceae were the main families, accounting for $26.7 \%, 6.7 \%, 6.7 \%$ and $5.8 \%$ of the total species, respectively. The geographical components of families and genera have obvious tropical properties, accounting for $51.3 \%$ and $66.6 \%$ of the total species, respectively. These originated mainly from South America and North America, accounting for $45.5 \%$ and $30.1 \%$ of the total frequency, respectively. Annual herbs, biennial herbs, and perennial herbs accounted for $84.6 \%$ of the total species. Based on a DPSIR conceptual model and an AHP method, an invasion risk assessment of 104 invasive alien plants was conducted. The ecological adaptability, habitat distribution and landscape impact of species were considered in the selection of indicators and the formulation of standards. A total of 23 high-risk invasive species were identified at level I, 37 medium-risk invasive species at level II, and 44 low-risk invasive species at level III. Lantana camara L. had the highest risk score (49), followed by Cenchrus echinatus L. (45), Spartina alterniflora Loisel. (45), and Panicum repens L. (43.5). Suggestions are put forward to prevent the invasion of alien plants on Pingtan Island and to provide a theoretical basis for promoting the healthy and stable development of the ecological environment on the island.
\end{abstract}

Keywords: alien invasive plants; intrusive analysis; risk assessment; Pingtan Island

\section{Introduction}

Invasive alien species (IAS) are those species that move beyond their natural distribution and spread, with the potential to spread and threaten local biodiversity and cause economic and ecological losses [1]. They do not only displace nearby indigenous plants and lead to habitat simplification but also cause severe economic damage by invading arable lands and tourist attractions [2]. The impacts of alien plants depend on various factors, such as species type, climate condition and native flora, as well as on the characteristics of the local ecosystem, with coastal areas, inland waters, and islands being the most affected [3]. The islands are vulnerable to typhoons, storm surges, and other natural disasters because 
of their scarce freshwater supply, thin soil, and poor vegetation cover [4]. As a result, island ecosystems have a very limited ability to self-regulate [4] and are vulnerable to alien plants. Moreover, due to the important role of islands in the marine economy, many countries put great effort into the development of island urbanization [5]. This triggers a series of ecological environmental problems, such as environmental degradation, coastal erosion, and biodiversity deterioration [6]. Therefore, it is necessary to study alien invasive plants on islands.

Pingtan Island is the fifth-largest island in China and the largest island in Fujian Province. It is the closest part of mainland China to Taiwan. In view of its special geographical location, Pingtan Island has become a comprehensive pilot area for island development and social and economic transformation and upgrades, and its development has received great attention. Pingtan Island is also a typical ecologically fragile island area with harsh natural conditions, such as high winds, drought, barren soil or exposed bedrock, high soil salt contents, and heavy salt fog, which restrict the growth of vegetation [7]. This field survey found that the plant community is relatively barren except for a few trees, mostly shrubs. Special geographical and climatic conditions, frequent external exchanges, and severely disturbed habitats provide favorable conditions for the arrival, survival, and expansion of alien plants, putting Pingtan Island at serious risk of alien plant invasion.

In order to prevent new plant invasions, there is an urgent need to develop early warning systems to determine the likelihood of a particular species becoming an invasive species, and to develop methods for rapidly assessing the status of invaders [8,9]. The invasion risk assessment is an assessment of the ecological and socio-economic impacts of alien species invasion, providing necessary information for the prioritization of biosecurity interventions for alien species and areas [10], especially in biodiversity hot spot territories [11], such as Pingtan Island. Because the harm caused by alien invasive plants varies greatly between different ecosystems and even in different habitats, the risk assessment index system suitable for one region may not be suitable for other regions [12]. Therefore, it is necessary to establish a risk assessment index system for invasive alien plants on Pingtan Island. At present, studies on invasive alien plants on Pingtan Island are relatively rare, mostly focusing on the flora [13], vegetation community diversity [14], plant resource evaluation [15], and the evolution mechanism of functional traits of island plants [16]. There are also studies on the influence of alien seed plants on the flora of native seed plants in Pingtan Island [3]. However, the invasive analysis of alien invasive plants on Pingtan Island is lacking.

The Driver-Pressure-State-Impact-Response (DPSIR) model is a conceptual model of an evaluation index system widely used in environmental systems [17]. The theoretical framework is as follows: driven by potential factors such as economic development and population increase, direct factors that destroy and interfere with the ecosystem are generated. These exert certain pressures on the ecosystem and have various effects on the environmental system, driving people to prevent, compensate, improve, or adapt to the environmental changes [17]. Based on the DPSIR conceptual model, this study evaluates the invasion risk of invasive alien plants on Pingtan Island from the following aspects: the driving force of invasive alien plants, their adaptability to the local environment, their distribution in the local area, their influence on the local area, and the response measures. Differing from the previous risk assessment index systems [18-20], this system is based on Pingtan Island. The weight focuses on the adaptation of alien invasive plants to salinity, high winds, drought, barren and waterlogged environments, the distribution of alien invasive plants in roadside wastelands, abandoned farmland, flower beds and lawns, and the impact on tourism. This study is the first detailed risk assessment of invasive alien plants on Pingtan Island. A brief analysis of their flora, which is beneficial for providing a scientific basis for the prevention and management of invasive alien plants on Pingtan Island, serves as a foundation for the risk assessment of invasive plants on the island and promotes the benign development of the local ecosystem. 


\section{Materials and Methods}

\subsection{Study Area}

Pingtan Island is the main part of Pingtan Comprehensive Experimental Area of Fujian Province, located in the southeast of Fujian Province $\left(25^{\circ} 15^{\prime}-25^{\circ} 45^{\prime} \mathrm{N}, 119^{\circ} 32^{\prime}-120^{\circ} 10^{\prime} \mathrm{E}\right.$, used by WGS84), covering an area of $324.13 \mathrm{~km}^{2}$. The region belongs to the south subtropical maritime monsoon climate, which is mild and humid, with an average mean annual temperature of $19.6^{\circ} \mathrm{C}$ and annual rainfall of $1172 \mathrm{~mm}$. The main meteorological disasters are typhoons, strong winds, heavy rain, and drought. The elevation of the terrain is higher in the north and south, with low hills. The highest peak, Junshan, is in the north, rising to $435 \mathrm{~m}$ above sea level. The central part is lower, and the landform type mainly consists of marine plains. The soil is mainly acrudox, udipsamments, and halaquepts. Vegetation types include a mixture of Pinus thunbergii Parl., Casuarina equisetifolia L., Acacia confusa Merr. and shrub-grass [4].

\subsection{Sample Site Survey}

According to the field investigation, land-use type, vegetation status, and ecological conditions, the main habitats of alien invasive plants were divided into six categories: roadside wastelands, abandoned farmlands, house areas, parterre and lawns, understory and forest edges, and seaside sandy land. Survey transect lines were distributed evenly throughout the study area. The transect lines crossed different habitats, and alien species and their basic conditions were recorded along the transect lines. At the same time, typical communities were selected for the sample survey. Since most of the invasive alien plants were herbaceous and few were low shrubs, the survey focused on scrub-grassland, and the quadrat was set as $2 \mathrm{~m} \times 2 \mathrm{~m}(4 \mathrm{~m} \times 1 \mathrm{~m}$ in the narrow area). A total of 29 sites were investigated (Figure 1), and 123 quadrats were set up. Among them, 39 were roadside wasteland, 25 were abandoned farmland, 18 were house areas, 15 were parterre and lawns, 14 were seaside sandy land, and 12 were understory and forest edges. The species, number of plants (clusters), average plant height, frequency, coverage, distribution abundance of species, and habitat type of distribution were recorded in the quadrats.

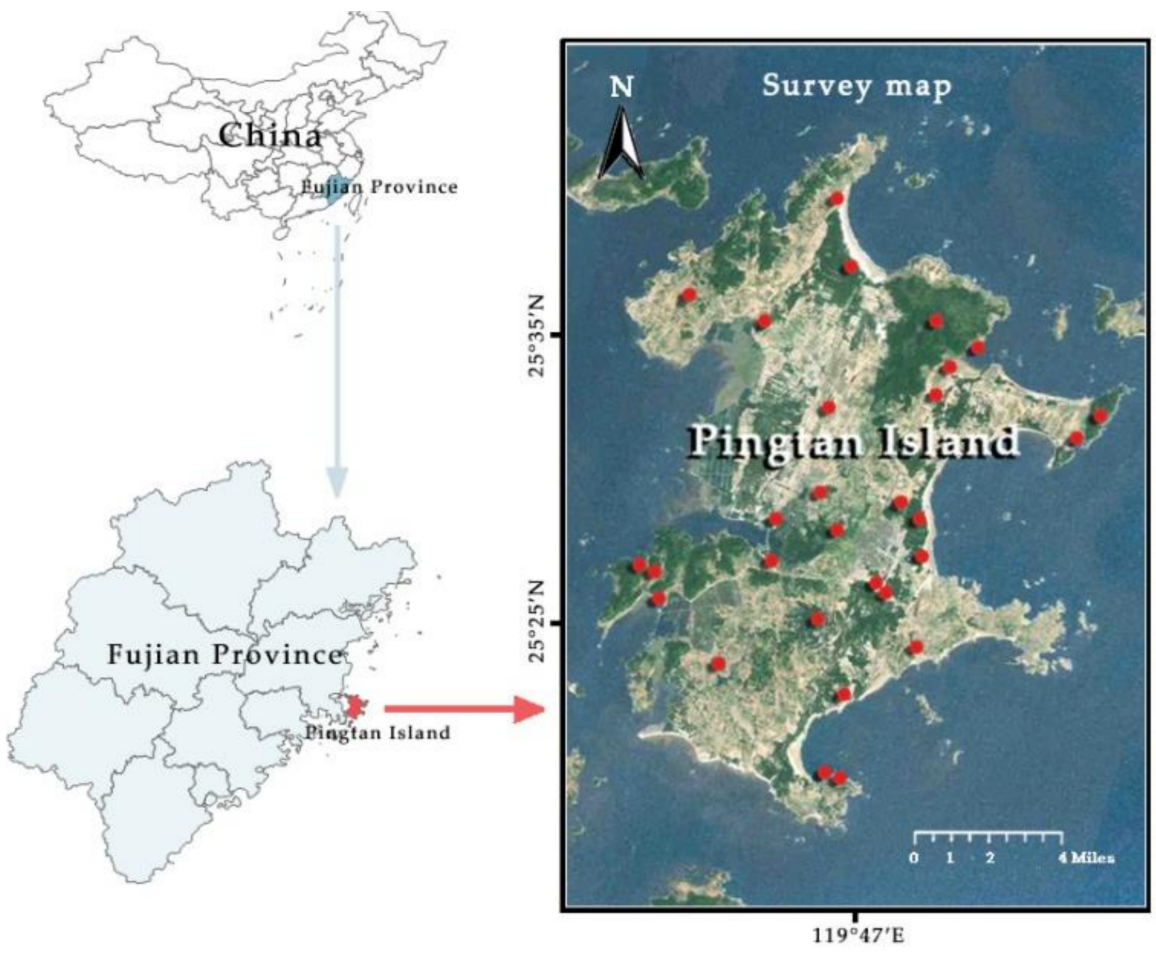

Figure 1. Survey map of investigation sites of alien invasive plants in Pingtan Island. 


\subsection{Determination of Alien Invasive Plants}

On the basis of the survey data of the sample site, with reference to professional literature, such as Flora of Fujian [21], Iplant [22], Exotic Plants of China [23], etc., the invasive alien species were selected and compiled into a list of invasive alien plants on Pingtan Island. The list does not include naturalized species, cultivated species that have not escaped, and those from other provinces in China.

\subsection{The Invasion of Risk Assessment}

This system finds a clearer idea from the DPSIR conceptual model: driven by their biological characteristics, alien invasive plants take root in the invasion site, and what state they are in under the environmental pressure of the invasion site, what harm they cause, and finally what prevention and control measures people take. On this basis, according to the growth and reproduction characteristics of invasive alien plants and their impacts on habitats investigated in the field, and by referring to the actual cases of invasive alien species and the risk assessment system [18-20] combined with the particularity of Pingtan Island's environment, 5 first-level indicators and 15 second-level indicators were determined. The 5 first-level indicators correspond to the five concepts of the DPSIR model. The driving force refers to the biological characteristics of invasive alien plants, including the life form, flowering period, propagation mode, and transmission capacity. The pressure refers to the pressure placed on the alien invasive plants in this area by the island environment, including the adaptability to salinity, high winds, drought, infertile and waterlogged conditions, and the environmental suitability of the climate, soil, and water. The state refers to the distribution state of alien invasive plants under local environmental pressures, including distribution density, habitat type, and importance value. The impact refers to the harm caused by alien invasive plants to the local area, including agriculture, forestry, fisheries, human and animal health, tourism, etc. The response refers to the feasibility of controlling alien invasive plants, including the validity period and effectiveness of controls. The specific conceptual model shown in Figure 2.

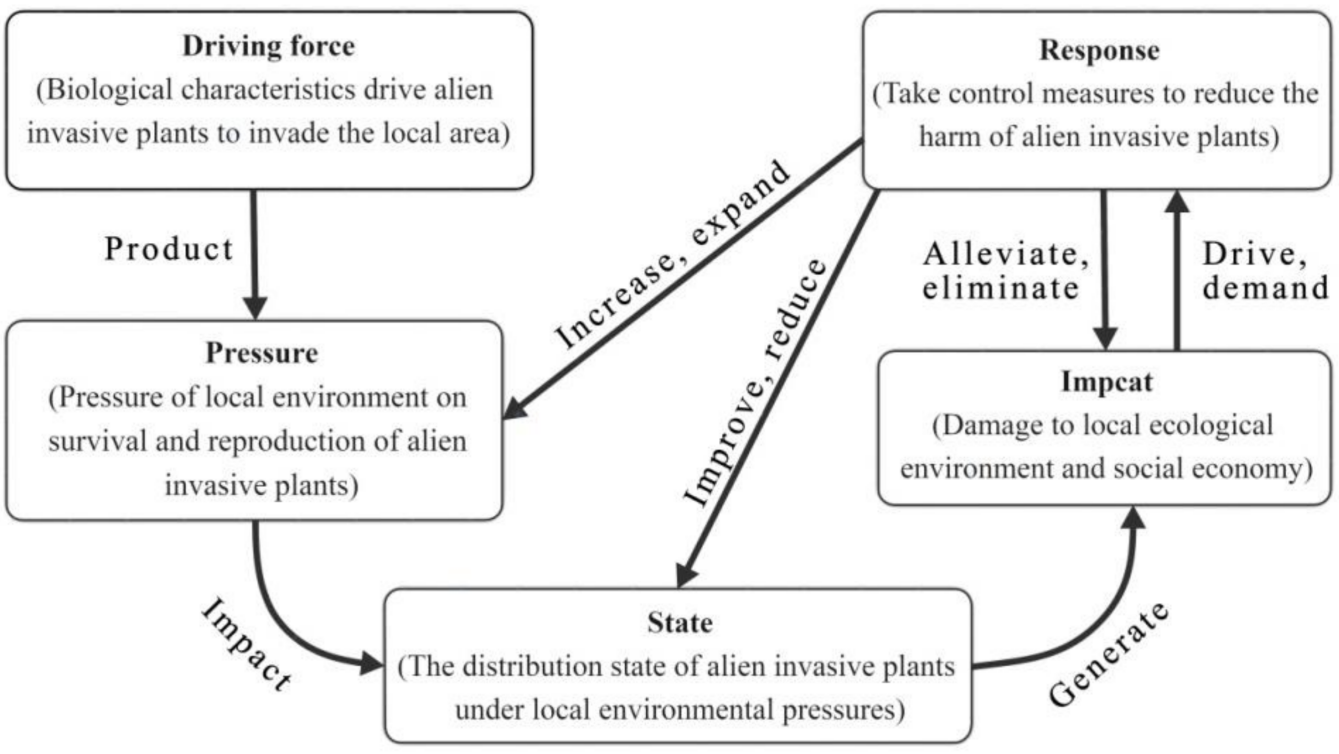

Figure 2. A conceptual model for risk assessment of invasive alien plants on Pingtan Island.

The Analytic Hierarchy Process (AHP) was used to determine the weight of each index in the intrusion risk assessment. The importance degree of each index was compared, several judgment matrices were constructed, the weight of the system index was determined via expert rating, and the consistency test was passed. The sum of the weight values of the first-level index was set as 100 points, the second-level index was the separated weight 
value of the first-level corresponding index, and the third-level index was the separated weight value of the second-level corresponding index [20]. The invasion risk levels of alien invasive plants were classified according to the results of the assessment.

\section{Results}

\subsection{Composition of Alien Invasive Plants}

There were 104 species from 80 genera and 37 families of alien invasive plants on Pingtan Island. Asteraceae, Fabaceae, Amaranthaceae, and Poaceae were the four families with the largest number of species, with 27, 7, 7, and 6 species, respectively. There were 19 monospecies, including Liliaceae, Aizoaceae, Cucurbitaceae, Zygophyllaceae, Basellaceae, and Cactaceae. Amaranthus L., Eupatorium L., Solanum L. and Euphorbia L. were the four most abundant genera with 5,3,3, and 3 species, respectively. The single genus included 60 members of the genera Ricinus L., Atriplex L., Zephyranthes Herb., Onopordum L., Pistia L., Atropa L. and Nasturtium Roth., etc.

\subsection{Origin}

The origin of alien invasive plants on Pingtan Island is classified according to the geographical seven continents (Figure 3). The plants native to America are counted once in South America and once in North America, the plants native to tropical America are counted once in South America, and the plants native to the Mediterranean region are counted once in Asia, Europe, and Africa. At a total frequency of 123, among them, 56 are native to South America, accounting for $45.5 \%$ of the total frequency. Another 37 species originated from North America, accounting for $30.1 \%$ of the total frequency. Fourteen species originated from Asia, accounting for $11.4 \%$ of the total frequency. Ten species originated from Europe, accounting for $8.1 \%$ of the total frequency. Five species originated from Africa, accounting for $4.1 \%$ of the total frequency. One species originated in Oceania. It can thus be seen that the alien invasive plants in Pingtan are mainly native to South America and North America.

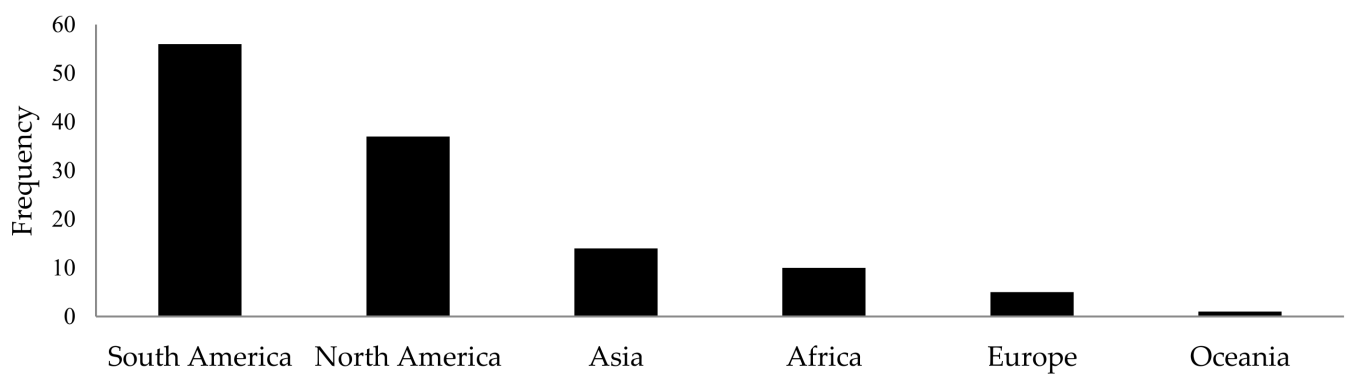

Figure 3. The origins of alien invasive plants found on Pingtan Island.

\subsection{Flora}

According to the classification principle of Wu Zhengyi et al. [24,25] on the distribution types of seed plant families and genera, the distribution areas of alien invasive plant families on Pingtan Island can be divided into four types (Table 1). Seventeen families are cosmopolitan, accounting for $45.9 \%$ of the total. Nineteen families are tropical, accounting for $51.3 \%$ of the total. Among them, 17 families are pantropical, which include the main components of the families of tropical nature. Two families are from East Asia and America. Only one family is of the temperate component. 
Table 1. Distribution areal types of families and genera of alien invasive plants in Pingtan Island.

\begin{tabular}{ccccc}
\hline Distribution Area Type & Families & Families \% & Genus & Genus \% \\
\hline 1 Cosmopolitan & 17 & 45.9 & 13 & 16.7 \\
2 Pantropic & 17 & 45.9 & 31 & 39.7 \\
3 East Asia and America Disjunct & 2 & 5.4 & 17 & 21.8 \\
4 Old World Tropics & - & - & 1 & 1.3 \\
6 Trop. Asia to Trop. Africa & - & - & 3 & 3.8 \\
8 North Temperate & 1 & 2.7 & 6 & 7.7 \\
10 Old World Temperate & - & - & 2 & 2.6 \\
12 Mediterranean region, West to & - & - & 5 & 6.4 \\
Central Asia & 37 & 100 & 78 & 100 \\
Total & & &
\end{tabular}

The distribution area of the genera can be divided into eight types. Thirteen genera are of cosmopolitan distribution, accounting for $16.7 \%$ of the total. Fifty-two genera are of tropical components, accounting for $66.6 \%$ of the total. Among them, 31 genera are of pantropical distribution, which are the main components of the genera of tropical nature. Seventeen genera are of East Asia and America. Only one genus was of old-world tropics. Three genera were of tropical Asia and tropical Africa. Thirteen genera were of temperate constituents, accounting for $16.7 \%$ of the total, a value which is $50.0 \%$ lower than that of the tropical components. Among them, six genera were of north temperate origin. Two genera were of old-world temperate origin. Five genera were from the Mediterranean region and West Asia to Central Asia. This shows that the geographical components of families and genera have obvious tropical properties.

\subsection{Life Forms}

Table 2 shows that annual and biennial herbs (49.0\%) and perennial herbs (35.6\%) accounted for the largest proportion of alien invasive plants on Pingtan Island, while vines and shrubs (15.4\%) accounted for the smaller proportion.

Table 2. Life forms of alien invasive plants on Pingtan Island.

\begin{tabular}{ccccc}
\hline Life Form & Families & Genus & Species & Species\% \\
\hline Annual herb & 16 & 33 & 41 & $39.4 \%$ \\
Biennial herb & 5 & 8 & 10 & $9.6 \%$ \\
Perennial herb & 20 & 32 & 37 & $35.6 \%$ \\
Herbaceous climber & 5 & 5 & 5 & $4.8 \%$ \\
Subshrubby herb & 3 & 5 & 5 & $4.8 \%$ \\
Shrub & 5 & 5 & 6 & $5.8 \%$ \\
Total & 54 & 88 & 104 & $100 \%$ \\
\hline
\end{tabular}

\subsection{Habitats}

The field survey results were combined with the literature from the above survey method to determine where invasive alien plants were likely to grow. As shown in Figure 4, there were 79 species in roadside wastelands and 67 species in abandoned farmlands, accounting for $27.1 \%$ and $22.9 \%$ of the total number of alien invasive plant species in each habitat, respectively. These are the two habitats with the most invasive alien plants. There were 43 species of parterre and lawn plants (14.7\%), 40 species in house areas $(13.7 \%), 33$ species in understory and forest edges (11.3\%), and 30 species of seaside sandy land (10.3\%). Among them, the representative species of diverse distribution habitats are Lantana camara L., Cenchrus echinatus L. and Panicum repens L. Less common are Macfadyena unguis-cati (L.) A. Gentry., Eichhornia crassipes (Mart.) Solms., Amaranthus viridis L., etc. In one habitat, 
there are Sesbania cannabina (Retz.) Poir., Atriplex patens (Litv.) Iljin., Opuntia stricta (Haw.) Haw., etc.

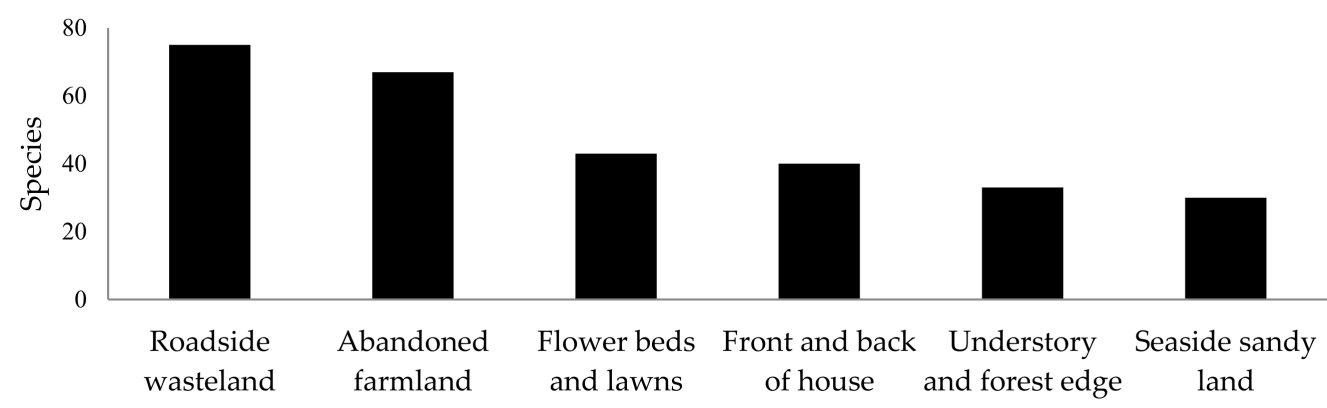

Figure 4. The habitats of alien invasive plants on Pingtan Island.

\subsection{Risk Assessment Results}

In the risk assessment system of invasive alien plants on Pingtan Island constructed in this study (Table 3), "0" indicates that the index does not play a role. According to Appendix A, the risk score $\mathrm{R}$ can be roughly divided into three levels (Table 4): $\mathrm{R} \geq 35$, high-risk I invasive species; $25 \leq \mathrm{R}<35$, medium-risk II invasive species; $\mathrm{R}<25$, low-risk III invasive species. The process of weight assignment see in the Supplementary Materials.

Table 3. The risk assessment index system used for alien invasive plants on Pingtan Island.

\begin{tabular}{|c|c|c|}
\hline First Level Index & Second Level Index & Indicator Connotation and Assignment \\
\hline \multirow{6}{*}{$\begin{array}{l}1 \text { The driving force of alien invasive plant } \\
\text { invasion (38) }\end{array}$} & 1.1 Life form (10) & $\begin{array}{c}\text { Shrub (4); Sub shrubby herb (3); Herbaceous } \\
\text { vine (2); Perennial herb (1); Annual or biennial } \\
\text { herb (0) }\end{array}$ \\
\hline & 1.2 Flowering duration (5) & $\begin{array}{l}\text { Long flowering period (>6 months) }(3) ; \\
\text { Mid-flowering period (5-6 months) }(2) ; \\
\text { Short flowering period (<5 months) }(0)\end{array}$ \\
\hline & 1.3 Modes of reproduction (10) & $\begin{array}{c}\text { Both seed propagation and vegetative } \\
\text { propagation (6); Seed propagation (3); } \\
\text { Vegetative reproduction (1) }\end{array}$ \\
\hline & 1.4 Seed fecundity (3) & $\begin{array}{l}\text { The seeds are large and easy to germinate (2); } \\
\text { The seed quantity is average and easy to } \\
\text { germinate (1); The number of seeds is small, or } \\
\text { are not easy to germinate }(0)\end{array}$ \\
\hline & 1.5 Invasion method (5) & $\begin{array}{c}\text { High possibility of intentional introduction (3); } \\
\text { Natural diffusion is more likely to be } \\
\text { introduced (2) }\end{array}$ \\
\hline & 1.6 Communication ability (5) & $\begin{array}{l}\text { Seeds can spread naturally over long distances } \\
\text { (3); Seeds spread naturally at close range (2) }\end{array}$ \\
\hline \multirow{3}{*}{$\begin{array}{l}2 \text { Adaptability of invasive alien plants to } \\
\text { the local environment (15) }\end{array}$} & $\begin{array}{l}\text { 2.1Adversity resistance } \\
\text { (adaptability to adversity, such as } \\
\text { salt-alkali, strong wind, drought, } \\
\text { barrenness, water logging, etc.) (8) }\end{array}$ & $\begin{array}{l}\text { Adapt to most adversities (5); Adapt to a few } \\
\text { adversities (2); Cannot adapt to such } \\
\text { adversities (1) }\end{array}$ \\
\hline & 2.2 Climatic suitability (2) & $\begin{array}{l}\text { Suitable for growth (2); Not suitable for } \\
\text { growth (0) }\end{array}$ \\
\hline & $\begin{array}{l}\text { 2.3 Soil and water environmental } \\
\text { suitability (5) }\end{array}$ & $\begin{array}{l}\text { Suitable for growth (4); Not suitable for } \\
\text { growth (1) }\end{array}$ \\
\hline
\end{tabular}


Table 3. Cont.

\begin{tabular}{|c|c|c|}
\hline First Level Index & Second Level Index & Indicator Connotation and Assignment \\
\hline \multirow{5}{*}{$\begin{array}{l}3 \text { Local distribution of alien invasive } \\
\text { plants (20) }\end{array}$} & 3.1 Distribution of abundance (6) & $\begin{array}{c}\text { Extremely common (3); Common (2); Locally } \\
\text { formed population (1); Unformed } \\
\text { population (0) }\end{array}$ \\
\hline & $\begin{array}{l}\text { 3.2 Distribution of habitat types } \\
\text { (roadside wasteland, abandoned } \\
\text { farmland, front and back of house, } \\
\text { parterre and lawns, understory } \\
\text { forest edge, seaside sandy land) (8) }\end{array}$ & $\begin{array}{c}\text { Distributed in 5-6 kinds of habitats (5); } \\
\text { Distributed in 3-4 habitats (2); Distributed in } \\
1-2 \text { kinds of habitats, or commonly seen in } \\
\text { cultivation (1) }\end{array}$ \\
\hline & 3.3 Important value (6) & $\begin{array}{c}\text { Important value }>10(3) ; 7 \mathrm{q} \leq \text { Important value } \\
<10(1.5) ; 4 \leq \text { Important value }<7(1) ; 1 \leq \\
\text { Important value }<4(0.5) ; \text { Important } \\
\text { value }<1(0)\end{array}$ \\
\hline & 4.1 Impact on native plants (2) & $\begin{array}{c}\text { Produce inhibiting effect (2); Does not produce } \\
\text { inhibition (0) }\end{array}$ \\
\hline & $\begin{array}{l}\text { 4.2 Impact on agriculture, forestry, } \\
\text { and fishery (1) }\end{array}$ & Has a certain hazard (1); No obvious hazard (0) \\
\hline \multirow[t]{2}{*}{$\begin{array}{c}4 \text { The impact of alien invasive plants on } \\
\text { the local area (9) }\end{array}$} & $\begin{array}{l}\text { 4.3 Impact on human and animal } \\
\text { health (1) }\end{array}$ & Has a certain hazard (1); No obvious hazard (0) \\
\hline & $\begin{array}{l}\text { 4.4 Impact on the tourist } \\
\text { landscape (5) }\end{array}$ & $\begin{array}{c}\text { Significant impact, serious harm (3); Have an } \\
\text { impact, but cause little harm (2); No obvious } \\
\text { hazard (0) }\end{array}$ \\
\hline 5 The response measures (18) & 5.1 Feasibility of prevention (18) & $\begin{array}{l}\text { No effective prevention measures, only } \\
\text { temporary control (10); Effective prevention } \\
\text { and treatment measures, obvious short-term } \\
\text { effects, easy to relapse (6); With effective } \\
\text { control measures, it can eliminate invasive } \\
\text { plants for a long time at one time (2); It has } \\
\text { medicinal, feed, edible, and ornamental values, } \\
\text { and no control measures have been taken (0) }\end{array}$ \\
\hline
\end{tabular}

Table 4. The risk assessment results of invasive alien plants on Pingtan Island.

\begin{tabular}{cccc}
\hline Risk Score $\mathbf{R}$ & Level & Species & Species\% \\
\hline $\mathrm{R} \geq 35$ & I high risk invasive species & 23 & 22.1 \\
$25 \leq \mathrm{R}<35$ & II medium risk invasive species & 37 & 35.6 \\
$\mathrm{R}<25$ & III low risk invasive species & 44 & 42.3 \\
\hline
\end{tabular}

As shown in Table 4, there are 23 high-risk I invasive species, accounting for $22.1 \%$ of the total. There were 37 risky invasive species in class II, accounting for $35.6 \%$ of the total. There were 44 low-risk invasive species of class III, accounting for $42.3 \%$ of the total. Lantana lantana L. had the highest risk score of 49. Among the species, Spartina alterniflora Loisel., Praxelis clematidea (Griseb.) R.King \& H.Rob., Ageratina adenophora (Sprengel) R. M. King \& H. Robinson., Ambrosia trifida L., Ambrosia artemisiifolia L., Solidago canadensis L., Pistia stratiotes L., Parthenium hysterophorus L., Amaranthus spinosus L., Sorghum halepense (L.) Pers. and Lolium temulentum L. were included in the four batches of Chinese invasive alien species list published by the Ministry of Ecology and Environment, PRC, and the State Key Invasive Alien Species List published by the Ministry of Agriculture and Rural Affairs [26-30]. Six plant species, Lantana camara L., Mikania micrantha Kunth., Sphagneticola trilobata, Eichhornia crassipes (L.) Pruski., Leucaena leucocephala (Lam.) de Wit. and Opuntia stricta (Haw.) Haw., are listed by the IUCN as among the 100 most harmful invasive species in the world [31]. 


\section{Discussion}

\subsection{Invasive Plants}

Asteraceae, Fabaceae, Amaranthus, and Poaceae are the main invasive plants on Pingtan Island. These families are cosmopolitan and have wide adaptability and resistance to adversity. South and North America are the main places of origin, which may be due to two reasons. First, the environment of the American tropics is similar to that of the southern coast of China. Second, relating to historical factors, the process of trade, politics, and cultural exchange leads to the unintentional introduction of alien invasive plants into cultivation, and at the same time adapts them to the local ecological environment. From the point of view of life forms, the herbaceous plants are dominated by annual and biennial, perennial herbs. Herbaceous plants have obvious advantages over native species when entering different places because of their characteristics, such as short life spans, rapid reproduction cycles, large number of seeds, small size, ease of dispersal, and strong invasion ability. In all kinds of habitats, whether in urban green belts and road networks or in rural farmland and ravines, the intensity of ecosystem disturbance is very high, facilitating the invasion of alien organisms [32].

Among the 104 alien invasive plants on Pingtan Island, 41 species (61\%) overlap with the 67 alien invasive plants in Xiamen [19], and 55 species (67\%) overlap with the 82 alien invasive plants in Fujian Province [33]. Compared with other invasive island plants, such as the 59 species in Dongshan Island of Fujian Province [34], there are more invasive species on Pingtan Island. This may be because the establishment of the coastal shelterbelt on Dongshan Island played an important role in improving the ecological environment. The repetition rate of the list of Pingtan Island's 104 species of invasive plants is highest, with Dongshan Island at 56\%, followed by Hainan Island with a repetition rate of $41 \%[34,35]$. This is possibly related to climate, as Pingtan and Dongshan Island belong to the subtropical maritime monsoon climate, while Hainan Island belongs to the tropical monsoon climate.

\subsection{Invasion Risk Assessment}

Many countries have established risk assessment systems for invasive alien plants, such as the typical Australian Weed Risk Assessment System (WRA), which is based on a series of questions in biogeography, unwelcome characteristics of species, biological or ecological characteristics, etc. [20]. Another example is the Central European Grading System for assessing the potential of non-native plant invasives (WG-WRA), which scores based on biogeography, ecology, and empirical relevance [18]. On the basis of previous studies, our system is also specially designed for Pingtan Island. In terms of index weight, the level I index focuses on the biological characteristics, local distribution, and historical control of alien invasive plants, which can reflect the adaptive relationship between alien invasive plants and the local environment and the resource competition relationship between invasive plants and local species. In the level II index, the weights mainly consider the adaptability of invasive plants to the special geographical conditions (salt, wind, drought, etc.) on Pingtan Island, the habitat types, important values of the distribution of invasive plants on the island, and the impact on the tourist landscape. By modifying some secondary indexes and related detailed criteria, the evaluation system can be more widely applied to plant invasion risk assessment in other areas. For example, in the secondary indicators, "2.1 Adversity resistance" should be set according to the specific adversity type of the study area, the same is true for "3.2 Distribution of habitat types". When assigning weight to indicators, it should also be adjusted according to the development attributes of the study area. In " 4 The impact of alien invasive plants on the local area", if the development of tourism economy is emphasized, the weight of tourism landscape impact should be correspondingly increased; if the development of agricultural economy is emphasized, the weight of agricultural impact should be increased.

Lantana camara L. had the highest risk score and is one of the top ten malignant weeds in the world. It can flower year-round and has a wide range of ornamental value. It is harmful to natural and agricultural ecosystems, especially to the native forests and the 
succession of understory vegetation [36], long-term suppression of the growth of invasive species, resulting in a significant decline in the abundance and richness of native species [37]. In addition, Lantana camara L. can spread agricultural diseases and pests and cause forest fires [38]. It can adapt to most of the adverse conditions on Pingtan Island. It is very common on Pingtan Island and distributed in all of the above six habitats. It is worth noting that the sixth most invasive plant in this study, Macfadyena unguis-cati (L.) A. Gentry., ranked first in the risk assessment of major invasive plants in Xiamen [18]. It is also an invasive plant that was originally cultivated as an ornamental. It often weaves on trees and shrubs, competing with them for sunlight and resulting in poor growth or death of its host. In the absence of climbers, the vines grow along the ground, forming a dense blanket that prevents understory growth and regeneration [39]. Therefore, ornamental plants are one of the important pathways of biological invasion [40]. Some of the low-risk invasive species of class III have ornamental functions that also deserve attention in application and management. For example, escaped Pilea microphylla (L.) Liebm., a common garden weed, will crowd out the local herbs; Opuntia stricta (Haw.) Haw. has caused invasions in Australia, South Africa, India, Spain, and many other places [41], and has been widely naturalized in the coastal areas of southern China, affecting the original coastal ecosystem and landscape [23]. In addition, perhaps due to time and the spatial limitations of the survey, the invasion risks of Cenchrus echinatus L. and Spartina alterniflora Loisel., which ranked first, were not included in the invasion list of Dongshan Island and Hainan Island discussed in 4.1. Ambrosia artemisiifolia L., Solidago canadensis L., Sorghum halepense (L.) Pers. and Ageratum conyzoides L. are well-known invasive species with poor invasion ability and belong to medium-risk invasive plants because it does not yet have formed or locally formed populations in the region, having few habitat types and low importance values.

The results of a survey reflect only the status of invasive plants. In fact, the invasiveness of species can only be reflected objectively through continuous observation over a period of time. For example, if a species has been present for 100 years, its distribution will naturally be large, which does not mean that it is very invasive. If a species has been present for 10 years, although the current distribution is not large, it may spread and develop rapidly. Future prevention and management strategies should focus on species with strong invasive abilities. At present, it is difficult to obtain historical survey observation data, so the evaluation results of this system are also deficient. Moreover, the evaluation of this system is a dynamic adjustment process, and the criteria under each index need to be modified and improved in the future, and its practicality must be evaluated through future work involving actual management of invasive plants.

For example, the feasibility of the prevention and control of invasive alien plants needs to be integrated with the improvement of their local control effects and control methods. Therefore, more in-depth investigations and research on the invasive alien plants of Pingtan Island are needed.

\subsection{Preventive Measures}

Suggestions for prevention and response mainly include the following: (1) The establishment of an institution and system for the prevention and control of alien invasive plants on Pingtan Island. (2) The strengthening of scientific assessment and prediction of invasive risk of alien plants, and the development of introduction plans. (3) According to the evaluation results, priority should be given to the prevention and control measures of high-risk invasive species, and re-introduction is not recommended. At the same time, attention should be paid to prevent accidental introduction. It is recommended that largescale introduction of medium-risk invasive species should be prohibited. If it is to be introduced, detailed information assessment should be carried out before introduction, and strict prevention and monitoring measures should be taken. Low-risk invasive species can be introduced but need to be monitored regularly. (4) Different habitats adopt different measures. For example, inspection and quarantine work should be strengthened on entry-exit cargo ships in coastal sands, and high-risk invasive species should be strictly 
prohibited. The islanders should be encouraged to reduce the invasion of alien plants via the exploitation of fertile fields. A management responsibility system should be established for grassland habitats in scenic spots to strengthen the effectiveness of their upkeep. A large number of empty houses and waste houses in rural and remote urban areas should be registered by the district management office and removed regularly. (5) Native tree species should be actively developed with a focus on protecting the remaining natural vegetation to build a stable community against the pressures brought by alien species. Tree species with distinctive seaside characteristics and typical island native plants, such as Eurya emarginata (Thunb.) Makino., Kandelia obovata Sheue, H.Y.Liu \& J.W.H.Yong. and Atriplex maximowicziana Makino., may be used for this [16]. Plant configurations should be optimized, with attention given to the combination of arbor, shrub, and grass. Their growth can prevent alien herbaceous plants from monopolizing the habitat. For example, Solidago canadensis L. do not tolerate shade, and there is basically no normal growth community found under tall and shaded trees.

\section{Conclusions}

Pingtan Island alien invasive plants, a total of 37 families and 80 genera and 104 species, Asteraceae, Fabaceae, Amaranthaceae, and Poaceae, were the main families. The geographical components of families and genera have obvious tropical affinities. Annual herbs, biennial herbs, and perennial herbs were examined. Their origins were mainly in South America and North America. A risk assessment index system for invasive alien plants on Pingtan Island was proposed, a total of 23 high-risk invasive species at level I, 25 mediumrisk invasive species at level II, and 44 low-risk invasive species at level III were identified. Lantana lantana L. had the highest risk score (49), followed by Cenchrus echinatus L., Spartina alterniflora Loisel., Panicum repens L., etc. These results provide a scientific basis for the control and management of invasive plants on Pingtan Island, and the designed system can be more widely applied to the risk assessment of invasive plants in other areas through appropriate modification of some secondary indicators and related detailed standards, so as to promote the sustainable development of ecological environment.

Supplementary Materials: The following are available online at https:/ /www.mdpi.com/article/10 $.3390 /$ su14020923/s1.

Author Contributions: Conceptualization, M.L. and K.L.; methodology, M.L., K.L. and S.Z.; software, M.L.; validation, X.C., L.X. and M.L.; formal analysis, M.L.; investigation, L.X., K.L., B.L., Z.H., J.L. and S.Z.; resources, K.L.; data curation, L.X. and X.C.; writing - original draft preparation, M.L.; writingreview and editing, S.Z.; visualization, M.L.; supervision, J.L.; project administration, B.L. and S.Z.; funding acquisition, B.L. All authors have read and agreed to the published version of the manuscript.

Funding: This research was funded by Investigation and Research Program of Forestry Alien Species in Fujian Province, grant number KJZXSA2018008.

Institutional Review Board Statement: Not applicable.

Informed Consent Statement: Not applicable.

Data Availability Statement: See in Supplementary Materials.

Acknowledgments: The authors sincerely thank the editors and anonymous reviewers for their kind views and constructive suggestions.

Conflicts of Interest: The authors declare no conflict of interest. 


\section{Appendix A}

Table A1. The specific scores of each index of risk assessment of alien invasive plants on Pingtan Island.

\begin{tabular}{|c|c|c|c|c|c|c|c|c|c|c|c|c|c|c|c|c|c|c|}
\hline Species & 1.1 & 1.2 & 1.3 & 1.4 & 1.5 & 1.6 & 2.1 & 2.2 & 2.3 & 3.1 & 3.2 & 3.3 & 4.1 & 4.2 & 4.3 & 4.4 & 5.1 & Total \\
\hline Lantana camara L. & 4 & 3 & 6 & 2 & 3 & 2 & 5 & 2 & 4 & 3 & 5 & 0 & 2 & 1 & 1 & 0 & 6 & 49.0 \\
\hline Cenchrus echinatus L. & 0 & 3 & 3 & 2 & 2 & 3 & 5 & 2 & 4 & 0 & 5 & 0 & 2 & 1 & 1 & 2 & 10 & 45.0 \\
\hline $\begin{array}{l}\text { Spartina alterniflora } \\
\text { Loisel. }\end{array}$ & 1 & 0 & 6 & 2 & 3 & 3 & 5 & 2 & 4 & 0 & 2 & 0 & 2 & 1 & 1 & 3 & 10 & 45.0 \\
\hline Panicum repens L. & 1 & 2 & 3 & 2 & 3 & 2 & 5 & 2 & 4 & 3 & 5 & 0.5 & 2 & 1 & 0 & 2 & 6 & 43.5 \\
\hline $\begin{array}{c}\text { Alternanthera } \\
\text { philoxeroides (Mart.) } \\
\text { Griseb. }\end{array}$ & 1 & 3 & 3 & 1 & 3 & 2 & 2 & 2 & 4 & 3 & 5 & 0.5 & 2 & 1 & 1 & 3 & 6 & 42.5 \\
\hline $\begin{array}{l}\text { Macfadyena unguis-cati } \\
\text { (L.) A. Gentry }\end{array}$ & 2 & 0 & 6 & 2 & 3 & 3 & 5 & 2 & 4 & 1 & 2 & 0 & 2 & 1 & 0 & 3 & 6 & 42.0 \\
\hline $\begin{array}{c}\text { Ageratina adenophora } \\
\text { (Sprengel) R. M. King \& } \\
\text { H. Robinson }\end{array}$ & 1 & 2 & 6 & 2 & 3 & 3 & 5 & 2 & 4 & 0 & 5 & 0 & 2 & 1 & 1 & 3 & 2 & 42.0 \\
\hline $\begin{array}{c}\text { Malvastrum } \\
\text { coromandelianum } \mathrm{L} \text {. }\end{array}$ & 3 & 3 & 6 & 2 & 2 & 2 & 5 & 2 & 1 & 2 & 5 & 0.5 & 2 & 1 & 0 & 2 & 2 & 40.5 \\
\hline $\begin{array}{c}\text { Praxelis clematidea } \\
\text { (Griseb.) R.King \& } \\
\text { H.Rob. }\end{array}$ & 1 & 3 & 3 & 2 & 2 & 2 & 2 & 2 & 4 & 3 & 5 & 1 & 2 & 1 & 1 & 0 & 6 & 40.0 \\
\hline $\begin{array}{l}\text { Mikania micrantha } \\
\text { Kunth. }\end{array}$ & 2 & 0 & 6 & 2 & 3 & 3 & 5 & 2 & 4 & 0 & 5 & 0 & 2 & 1 & 0 & 3 & 2 & 40.0 \\
\hline Phytolacca americana L. & 1 & 0 & 6 & 2 & 3 & 3 & 5 & 2 & 4 & 0 & 5 & 0 & 2 & 1 & 1 & 3 & 2 & 40.0 \\
\hline Bidens pilosa $\mathrm{L}$. & 0 & 0 & 3 & 2 & 2 & 3 & 2 & 2 & 4 & 3 & 5 & 3 & 2 & 1 & 0 & 2 & 6 & 40.0 \\
\hline $\begin{array}{l}\text { Tithonia diversifolia } \\
\text { (Hemsl.) A.Gray }\end{array}$ & 0 & 3 & 6 & 2 & 3 & 3 & 5 & 2 & 4 & 0 & 2 & 0 & 2 & 1 & 0 & 0 & 6 & 39.0 \\
\hline $\begin{array}{c}\text { Sphagneticola trilobata (L.) } \\
\text { Pruski }\end{array}$ & 1 & 3 & 6 & 2 & 3 & 3 & 5 & 2 & 4 & 0 & 5 & 0 & 2 & 1 & 0 & 0 & 2 & 39.0 \\
\hline Phytolacca acinosa Roxb. & 1 & 0 & 6 & 2 & 3 & 3 & 5 & 2 & 4 & 0 & 5 & 0 & 2 & 1 & 0 & 3 & 2 & 39.0 \\
\hline $\begin{array}{l}\text { Chromolaena odorata (L.) } \\
\text { R.King \& H.Rob. }\end{array}$ & 1 & 2 & 6 & 2 & 3 & 3 & 5 & 2 & 4 & 0 & 2 & 0 & 2 & 1 & 1 & 2 & 2 & 38.0 \\
\hline Datura stramonium L. & 0 & 0 & 6 & 2 & 2 & 3 & 5 & 2 & 4 & 0 & 5 & 0 & 2 & 1 & 1 & 2 & 2 & 37.0 \\
\hline $\begin{array}{l}\text { Eichhornia crassipes } \\
\text { (Mart.) Solms }\end{array}$ & 0 & 0 & 6 & 2 & 3 & 3 & 5 & 2 & 4 & 0 & 2 & 0 & 2 & 1 & 1 & 3 & 2 & 36.0 \\
\hline Ambrosia trifida L. & 0 & 0 & 3 & 2 & 3 & 5 & 5 & 2 & 4 & 0 & 2 & 0 & 2 & 1 & 1 & 0 & 6 & 36.0 \\
\hline Amaranthus viridis L. & 0 & 0 & 3 & 2 & 2 & 2 & 5 & 2 & 4 & 2 & 2 & 0.5 & 2 & 1 & 0 & 2 & 6 & 35.5 \\
\hline $\begin{array}{c}\text { Symphyotrichum } \\
\text { subulatum (Michx.) } \\
\text { G.L.Nesom }\end{array}$ & 1 & 0 & 3 & 2 & 2 & 3 & 2 & 2 & 4 & 3 & 5 & 1.5 & 2 & 1 & 0 & 2 & 2 & 35.5 \\
\hline Oxalis pes-caprae $\mathrm{L}$. & 1 & 2 & 6 & 2 & 3 & 2 & 2 & 2 & 4 & 0 & 2 & 0 & 2 & 1 & 0 & 0 & 6 & 35.0 \\
\hline $\begin{array}{c}\text { Flaveria bidentis (L.) } \\
\text { Kuntze }\end{array}$ & 0 & 0 & 6 & 2 & 2 & 3 & 5 & 2 & 4 & 1 & 1 & 0 & 2 & 1 & 0 & 0 & 6 & 35.0 \\
\hline Ambrosia artemisiifolia $\mathrm{L}$. & 0 & 0 & 3 & 2 & 3 & 3 & 5 & 2 & 4 & 0 & 2 & 0 & 2 & 1 & 1 & 0 & 6 & 34.0 \\
\hline Solidago canadensis L. & 1 & 0 & 6 & 2 & 3 & 3 & 5 & 2 & 4 & 0 & 2 & 0 & 2 & 1 & 1 & 0 & 2 & 34.0 \\
\hline $\begin{array}{c}\text { Sorghum halepense (L.) } \\
\text { Pers. }\end{array}$ & 0 & 0 & 6 & 2 & 2 & 3 & 5 & 2 & 4 & 1 & 1 & 0 & 2 & 1 & 1 & 2 & 2 & 34.0 \\
\hline Erigeron canadensis L. & 0 & 0 & 3 & 2 & 2 & 3 & 2 & 2 & 4 & 3 & 5 & 0.5 & 2 & 1 & 0 & 2 & 2 & 33.5 \\
\hline $\begin{array}{c}\text { Anredera cordifolia (Ten.) } \\
\text { Steenis }\end{array}$ & 2 & 2 & 6 & 0 & 3 & 2 & 2 & 2 & 4 & 1 & 2 & 0.5 & 2 & 1 & 0 & 2 & 2 & 33.5 \\
\hline Amaranthus retroflexus L. & 0 & 0 & 3 & 2 & 3 & 3 & 5 & 2 & 4 & 0 & 5 & 0 & 2 & 1 & 1 & 0 & 2 & 33.0 \\
\hline Ricinus communis L. & 0 & 0 & 3 & 2 & 3 & 2 & 2 & 2 & 4 & 1 & 5 & 0.5 & 2 & 1 & 1 & 2 & 2 & 32.5 \\
\hline Scoparia dulcis L. & 0 & 3 & 3 & 1 & 3 & 3 & 5 & 2 & 4 & 0 & 5 & 0 & 0 & 1 & 0 & 0 & 2 & 32.0 \\
\hline Erigeron annuus (L.) Pers. & 0 & 0 & 3 & 2 & 3 & 3 & 5 & 2 & 4 & 3 & 2 & 0 & 2 & 1 & 0 & 0 & 2 & 32.0 \\
\hline $\begin{array}{c}\text { Solanum rostratum } \\
\text { Dunal. }\end{array}$ & 0 & 0 & 6 & 2 & 2 & 3 & 2 & 2 & 4 & 1 & 1 & 0 & 2 & 1 & 0 & 0 & 6 & 32.0 \\
\hline $\begin{array}{l}\text { Soliva anthemifolia (Juss.) } \\
\text { R.Br. ex Less. }\end{array}$ & 0 & 3 & 3 & 2 & 2 & 2 & 5 & 2 & 4 & 0 & 2 & 0 & 2 & 1 & 0 & 2 & 2 & 32.0 \\
\hline
\end{tabular}


Table A1. Cont.

\begin{tabular}{|c|c|c|c|c|c|c|c|c|c|c|c|c|c|c|c|c|c|c|}
\hline Species & 1.1 & 1.2 & 1.3 & 1.4 & 1.5 & 1.6 & 2.1 & 2.2 & 2.3 & 3.1 & 3.2 & 3.3 & 4.1 & 4.2 & 4.3 & 4.4 & 5.1 & Total \\
\hline Galinsoga parviflora Cav. & 0 & 0 & 3 & 2 & 3 & 3 & 2 & 2 & 4 & 0 & 5 & 0 & 2 & 1 & 0 & 2 & 2 & 31.0 \\
\hline Euphorbia dentata Michx. & 0 & 0 & 6 & 2 & 2 & 3 & 2 & 2 & 4 & 0 & 1 & 0 & 2 & 1 & 0 & 0 & 6 & 31.0 \\
\hline Sonchus oleraceus L. & 0 & 2 & 3 & 2 & 2 & 2 & 5 & 2 & 4 & 0 & 2 & 0 & 2 & 1 & 0 & 2 & 2 & 31.0 \\
\hline $\begin{array}{c}\text { Crassocephalum } \\
\text { crepidioides (Benth.) S. } \\
\text { Moore }\end{array}$ & 0 & 3 & 2 & 3 & 2 & 2 & 2 & 4 & 1 & 1 & 0 & 0 & 2 & 1 & 0 & 2 & 6 & 31.0 \\
\hline Euphorbia hirta L. & 0 & 2 & 3 & 2 & 3 & 2 & 2 & 2 & 4 & 2 & 2 & 0.5 & 2 & 1 & 1 & 0 & 2 & 30.5 \\
\hline $\begin{array}{c}\text { Oenothera drummondii } \\
\text { Hook. }\end{array}$ & 1 & 0 & 6 & 2 & 3 & 2 & 5 & 2 & 4 & 1 & 2 & 0.5 & 0 & 0 & 0 & 0 & 2 & 30.5 \\
\hline Erigeron bonariensis L. & 0 & 2 & 3 & 2 & 3 & 3 & 2 & 2 & 4 & 0 & 1 & 0 & 2 & 1 & 1 & 2 & 2 & 30.0 \\
\hline Ipomoea cairica (L.) Sweet & 1 & 3 & 6 & 1 & 2 & 2 & 2 & 2 & 4 & 1 & 1 & 0 & 2 & 1 & 0 & 0 & 2 & 30.0 \\
\hline Ageratum conyzoides L. & 0 & 3 & 6 & 2 & 2 & 2 & 2 & 2 & 4 & 0 & 1 & 0 & 2 & 1 & 0 & 0 & 2 & 29.0 \\
\hline $\begin{array}{l}\text { Leucaena leucocephala } \\
\text { (Lam.) de Wit }\end{array}$ & 4 & 0 & 6 & 2 & 3 & 2 & 2 & 2 & 4 & 1 & 2 & 0 & 0 & 0 & 1 & 0 & 0 & 29.0 \\
\hline Agave americana $\mathrm{L}$. & 1 & 0 & 6 & 2 & 3 & 3 & 2 & 2 & 4 & 0 & 2 & 0 & 0 & 1 & 1 & 0 & 2 & 29.0 \\
\hline $\begin{array}{l}\text { Sphagneticola calendulacea } \\
\text { (L.) Pruski }\end{array}$ & 1 & 3 & 1 & 0 & 2 & 3 & 5 & 2 & 4 & 0 & 5 & 0 & 2 & 1 & 0 & 0 & 0 & 29.0 \\
\hline Mimosa pudica L. & 3 & 3 & 3 & 1 & 3 & 3 & 2 & 2 & 4 & 1 & 1 & 0 & 2 & 0 & 1 & 0 & 0 & 29.0 \\
\hline Chenopodium glaucum L. & 0 & 0 & 3 & 2 & 2 & 3 & 5 & 2 & 4 & 1 & 2 & 0 & 2 & 1 & 0 & 0 & 2 & 29.0 \\
\hline $\begin{array}{c}\text { Dysphania ambrosioides } \\
\text { (L.) Mosyakin \& } \\
\text { Clemants }\end{array}$ & 1 & 0 & 3 & 2 & 2 & 2 & 2 & 2 & 4 & 1 & 1 & 0 & 2 & 1 & 1 & 2 & 2 & 28.0 \\
\hline Solanum torvum Sw. & 4 & 3 & 6 & 2 & 3 & 2 & 2 & 2 & 1 & 1 & 2 & 0 & 0 & 0 & 0 & 0 & 0 & 28.0 \\
\hline Pistia stratiotes L. & 1 & 0 & 6 & 1 & 3 & 3 & 2 & 0 & 4 & 0 & 2 & 0 & 2 & 1 & 0 & 2 & 0 & 27.0 \\
\hline Spermacoce alata Aublet. & 0 & 0 & 6 & 0 & 3 & 2 & 2 & 2 & 4 & 0 & 2 & 0 & 2 & 1 & 1 & 0 & 2 & 27.0 \\
\hline Oenothera biennis L. & 0 & 0 & 6 & 1 & 3 & 2 & 2 & 2 & 4 & 0 & 5 & 0 & 2 & 0 & 0 & 0 & 0 & 27.0 \\
\hline $\begin{array}{c}\text { Parthenium hysterophorus } \\
\text { L. }\end{array}$ & 0 & 0 & 3 & 2 & 2 & 2 & 2 & 2 & 4 & 0 & 2 & 0 & 2 & 1 & 1 & 2 & 2 & 27.0 \\
\hline Lepidium virginicum $\mathrm{L}$. & 0 & 0 & 3 & 2 & 2 & 2 & 2 & 2 & 4 & 0 & 2 & 0 & 2 & 1 & 0 & 2 & 2 & 26.0 \\
\hline $\begin{array}{c}\text { Solanum pseudocapsicum } \\
\text { L. }\end{array}$ & 4 & 0 & 6 & 1 & 3 & 2 & 2 & 2 & 4 & 0 & 1 & 0 & 0 & 0 & 1 & 0 & 0 & 26.0 \\
\hline $\begin{array}{l}\text { Bryophyllum pinnatum } \\
\text { (Lam.) Oken }\end{array}$ & 1 & 0 & 6 & 1 & 2 & 3 & 5 & 2 & 4 & 1 & 1 & 0 & 0 & 0 & 0 & 0 & 0 & 26.0 \\
\hline Oxalis corymbosa DC. & 1 & 0 & 6 & 2 & 3 & 3 & 2 & 2 & 1 & 1 & 1 & 0 & 2 & 0 & 0 & 0 & 2 & 26.0 \\
\hline $\begin{array}{c}\text { Crotalaria trichotoma } \\
\text { Bojer. }\end{array}$ & 3 & 2 & 3 & 1 & 3 & 2 & 2 & 2 & 4 & 0 & 1 & 0 & 2 & 0 & 0 & 0 & 0 & 25.0 \\
\hline $\begin{array}{c}\text { Cuphea hyssopifolia } \\
\text { Kunth. }\end{array}$ & 4 & 3 & 3 & 1 & 3 & 2 & 2 & 2 & 4 & 0 & 1 & 0 & 0 & 0 & 0 & 0 & 0 & 25.0 \\
\hline Amaranthus spinosus L. & 0 & 0 & 3 & 2 & 2 & 2 & 2 & 2 & 1 & 1 & 1 & 0 & 2 & 1 & 1 & 2 & 2 & 24.0 \\
\hline Paspalum urvillei Steud. & 1 & 0 & 3 & 2 & 3 & 2 & 2 & 2 & 4 & 2 & 1 & 0 & 0 & 0 & 0 & 0 & 2 & 24.0 \\
\hline $\begin{array}{l}\text { Tetragonia tetragonioides } \\
\text { (Pallas) Kuntze. }\end{array}$ & 0 & 0 & 3 & 2 & 3 & 3 & 5 & 2 & 4 & 0 & 2 & 0 & 0 & 0 & 0 & 0 & 0 & 24.0 \\
\hline Daucus carota $\mathrm{L}$. & 0 & 0 & 3 & 2 & 2 & 3 & 2 & 2 & 4 & 0 & 1 & 0 & 2 & 1 & 0 & 0 & 2 & 24.0 \\
\hline Amaranthus blitum $\mathrm{L}$. & 0 & 0 & 3 & 2 & 2 & 2 & 5 & 2 & 4 & 1 & 2 & 0 & 0 & 0 & 0 & 0 & 0 & 23.0 \\
\hline Mirabilis jalapa L. & 0 & 0 & 6 & 1 & 3 & 2 & 2 & 2 & 1 & 0 & 1 & 0 & 2 & 0 & 1 & 0 & 2 & 23.0 \\
\hline $\begin{array}{l}\text { Pilea microphylla (L.) } \\
\text { Liebm. }\end{array}$ & 1 & 0 & 6 & 2 & 3 & 2 & 2 & 2 & 1 & 0 & 1 & 0 & 2 & 1 & 0 & 0 & 0 & 23.0 \\
\hline $\begin{array}{c}\text { Opuntia stricta (Haw.) } \\
\text { Haw. }\end{array}$ & 4 & 0 & 6 & 1 & 3 & 2 & 2 & 2 & 1 & 1 & 1 & 0 & 0 & 0 & 0 & 0 & 0 & 23.0 \\
\hline Celosia argentea L. & 0 & 0 & 3 & 2 & 3 & 2 & 2 & 2 & 4 & 0 & 2 & 0 & 2 & 1 & 0 & 0 & 0 & 23.0 \\
\hline Passiflora suberosa L. & 2 & 0 & 6 & 2 & 3 & 2 & 2 & 2 & 1 & 1 & 2 & 0 & 0 & 0 & 0 & 0 & 0 & 23.0 \\
\hline Erigeron acris L. & 0 & 0 & 3 & 2 & 2 & 3 & 5 & 2 & 4 & 1 & 1 & 0 & 0 & 0 & 0 & 0 & 0 & 23.0 \\
\hline Sonchus asper (L.) Hill. & 0 & 2 & 3 & 1 & 2 & 2 & 2 & 2 & 1 & 0 & 1 & 0 & 2 & 1 & 0 & 2 & 2 & 23.0 \\
\hline $\begin{array}{l}\text { Cuphea carthagenensis } \\
\text { (Jacq.) J. F. Macbr. }\end{array}$ & 0 & 2 & 6 & 1 & 3 & 2 & 2 & 2 & 4 & 0 & 1 & 0 & 0 & 0 & 0 & 0 & 0 & 23.0 \\
\hline Amaranthus tricolor $\mathrm{L}$. & 0 & 0 & 3 & 2 & 3 & 3 & 2 & 2 & 4 & 0 & 1 & 0 & 2 & 1 & 0 & 0 & 0 & 23.0 \\
\hline Callisia repens L. & 1 & 0 & 6 & 2 & 3 & 2 & 2 & 2 & 4 & 0 & 1 & 0 & 0 & 0 & 0 & 0 & 0 & 23.0 \\
\hline
\end{tabular}


Table A1. Cont.

\begin{tabular}{|c|c|c|c|c|c|c|c|c|c|c|c|c|c|c|c|c|c|c|}
\hline Species & 1.1 & 1.2 & 1.3 & 1.4 & 1.5 & 1.6 & 2.1 & 2.2 & 2.3 & 3.1 & 3.2 & 3.3 & 4.1 & 4.2 & 4.3 & 4.4 & 5.1 & Total \\
\hline $\begin{array}{c}\text { Sesbania cannabina (Retz.) } \\
\text { Poir. }\end{array}$ & 0 & 0 & 3 & 1 & 3 & 2 & 5 & 2 & 4 & 1 & 1 & 0 & 0 & 0 & 0 & 0 & 0 & 22.0 \\
\hline Portulaca pilosa $\mathrm{L}$. & 1 & 0 & 3 & 2 & 2 & 2 & 2 & 2 & 4 & 1 & 1 & 0 & 2 & 0 & 0 & 0 & 0 & 22.0 \\
\hline Atropa belladonna L. & 1 & 0 & 3 & 2 & 3 & 2 & 2 & 2 & 1 & 1 & 1 & 0 & 0 & 1 & 1 & 0 & 2 & 22.0 \\
\hline Ocimum basilicum $\mathrm{L}$. & 0 & 0 & 6 & 1 & 3 & 2 & 2 & 2 & 4 & 1 & 1 & 0 & 0 & 0 & 0 & 0 & 0 & 22.0 \\
\hline $\begin{array}{l}\text { Atriplex patens (Litv.) } \\
\text { Iljin }\end{array}$ & 0 & 0 & 3 & 2 & 2 & 2 & 5 & 2 & 4 & 0 & 1 & 0 & 0 & 0 & 1 & 0 & 0 & 22.0 \\
\hline Ipomoea nil (L.) Roth & 0 & 2 & 3 & 2 & 3 & 3 & 2 & 2 & 4 & 0 & 1 & 0 & 0 & 0 & 0 & 0 & 0 & 22.0 \\
\hline $\begin{array}{l}\text { Ipomoea purpurea (L.) } \\
\text { Roth }\end{array}$ & 0 & 2 & 3 & 2 & 3 & 3 & 2 & 2 & 4 & 0 & 1 & 0 & 0 & 0 & 0 & 0 & 0 & 22.0 \\
\hline $\begin{array}{c}\text { Euphorbia cyathophora } \\
\text { Murr. }\end{array}$ & 1 & 2 & 6 & 1 & 2 & 2 & 2 & 2 & 1 & 0 & 1 & 0 & 0 & 0 & 1 & 0 & 0 & 21.0 \\
\hline Aloe vera $\mathrm{L}$. & 1 & 0 & 6 & 0 & 3 & 2 & 2 & 2 & 4 & 0 & 1 & 0 & 0 & 0 & 0 & 0 & 0 & 21.0 \\
\hline Tephrosia candida DC. & 3 & 0 & 3 & 1 & 3 & 2 & 2 & 2 & 4 & 0 & 1 & 0 & 0 & 0 & 0 & 0 & 0 & 21.0 \\
\hline Lolium temulentum $\mathrm{L}$. & 0 & 0 & 3 & 2 & 2 & 3 & 2 & 2 & 1 & 0 & 1 & 0 & 2 & 0 & 1 & 0 & 2 & 21.0 \\
\hline Cosmos bipinnatus Cav. & 1 & 0 & 3 & 2 & 3 & 2 & 2 & 2 & 4 & 0 & 1 & 0 & 0 & 0 & 1 & 0 & 0 & 21.0 \\
\hline Hyssopus officinalis L. & 1 & 0 & 6 & 2 & 3 & 2 & 2 & 2 & 1 & 0 & 1 & 0 & 0 & 0 & 0 & 0 & 0 & 20.0 \\
\hline Vicia sativa L. & 0 & 0 & 3 & 2 & 2 & 3 & 2 & 2 & 1 & 0 & 1 & 0 & 0 & 1 & 1 & 0 & 2 & 20.0 \\
\hline Hibiscus sabdariffa L. & 0 & 2 & 3 & 1 & 3 & 2 & 2 & 2 & 4 & 0 & 1 & 0 & 0 & 0 & 0 & 0 & 0 & 20.0 \\
\hline Raphanus raphanistrum $\mathrm{L}$. & 0 & 0 & 3 & 2 & 2 & 2 & 2 & 2 & 4 & 0 & 1 & 0 & 0 & 0 & 0 & 0 & 2 & 20.0 \\
\hline Impatiens balsamina $\mathrm{L}$. & 0 & 0 & 6 & 2 & 3 & 2 & 1 & 2 & 1 & 0 & 1 & 0 & 0 & 0 & 0 & 0 & 0 & 18.0 \\
\hline Bidens frondosa $\mathrm{L}$. & 0 & 0 & 3 & 2 & 2 & 3 & 2 & 2 & 1 & 0 & 1 & 0 & 0 & 0 & 0 & 0 & 2 & 18.0 \\
\hline Canna indica L. & 1 & 0 & 3 & 0 & 3 & 2 & 1 & 2 & 4 & 0 & 1 & 0 & 0 & 1 & 0 & 0 & 0 & 18.0 \\
\hline $\begin{array}{c}\text { Tradescantia zebrina } \\
\text { Bosse. }\end{array}$ & 1 & 0 & 6 & 0 & 3 & 2 & 2 & 2 & 1 & 0 & 1 & 0 & 0 & 0 & 0 & 0 & 0 & 18.0 \\
\hline Tribulus terrestris L. & 0 & 0 & 3 & 1 & 2 & 3 & 2 & 1 & 4 & 0 & 1 & 0 & 0 & 0 & 0 & 0 & 0 & 17.0 \\
\hline Ipomoea triloba L. & 0 & 0 & 3 & 0 & 2 & 2 & 2 & 2 & 1 & 1 & 2 & 0 & 2 & 0 & 0 & 0 & 0 & 17.0 \\
\hline $\begin{array}{l}\text { Talinum paniculatum } \\
\text { (Jacq.) Gaertn. }\end{array}$ & 1 & 0 & 3 & 1 & 3 & 2 & 1 & 2 & 1 & 0 & 1 & 0 & 0 & 0 & 1 & 0 & 0 & 16.0 \\
\hline $\begin{array}{l}\text { Zehneria japonica } \\
\text { (Thunb.) H.Y.Liu }\end{array}$ & 1 & 0 & 3 & 1 & 3 & 2 & 2 & 2 & 1 & 0 & 1 & 0 & 0 & 0 & 0 & 0 & 0 & 16.0 \\
\hline $\begin{array}{c}\text { Nasturtium officinale R. } \\
\text { Br. }\end{array}$ & 1 & 0 & 6 & 0 & 3 & 2 & 1 & 0 & 1 & 0 & 1 & 0 & 0 & 0 & 0 & 0 & 0 & 15.0 \\
\hline Onopordum acanthium L. & 0 & 0 & 3 & 2 & 2 & 3 & 2 & 0 & 1 & 0 & 1 & 0 & 0 & 0 & 0 & 0 & 0 & 14.0 \\
\hline Lepidium apetalum Willd. & 0 & 0 & 3 & 0 & 3 & 2 & 2 & 2 & 1 & 0 & 1 & 0 & 0 & 0 & 0 & 0 & 0 & 14.0 \\
\hline $\begin{array}{l}\text { Zephyranthes candida } \\
\text { (Lindl.) Herb. }\end{array}$ & 1 & 0 & 3 & 1 & 3 & 2 & 0 & 2 & 1 & 0 & 1 & 0 & 0 & 0 & 0 & 0 & 0 & 14.0 \\
\hline Astragalus sinicus L. & 0 & 0 & 3 & 1 & 2 & 2 & 1 & 2 & 1 & 0 & 1 & 0 & 0 & 0 & 0 & 0 & 0 & 13.0 \\
\hline
\end{tabular}

\section{References}

1. Jiang, H.; Fan, Q.; Li, J.T.; Shi, S.; Li, S.P.; Liao, W.B.; Shu, W.S. Naturalization of alien plants in China. Biodivers. Conserv. 2011, 20, 1545-1556. [CrossRef]

2. Eunyoung, K.; Jaeyong, C.; Wonkyong, S. Introduction and Spread of the Invasive Alien Species Ageratina altissima in a Disturbed Forest Ecosystem. Sustainability 2021, 13, 6152.

3. Ye, Z.Y. Flora of seed plants in Pingtan Island, Fujian and effects of exotic plants. Guihaia 2017, 37, $280-293$.

4. Zheng, W.H.; Cai, F.; Chen, S.; Zhu, J.; Qi, H.; Zhao, S.; Liu, J. Ecological Suitability of Island Development Based on Ecosystem Services Value, Biocapacity and Ecological Footprint: A Case Study of Pingtan Island, Fujian, China. Sustainability 2020, $12,2553$. [CrossRef]

5. Zhang, H.; Xiao, Y.; Deng, Y. Island Ecosystem Evaluation and Sustainable Development Strategies: A Case Study of the Zhoushan Archipelago. Glob. Ecol. Conserv. 2021, 28, e01603. [CrossRef]

6. Cao, W.; Li, R.; Chi, X.; Chen, N.; Chen, J.; Zhang, H.; Zhang, F. Island urbanization and its ecological consequences: A case study in the Zhoushan Island, East China. Ecol. Indic. 2017, 76, 1-14. [CrossRef]

7. Wen, X.; Ming, Y.; Gao, Y.; Hu, X. Dynamic Monitoring and Analysis of Ecological Quality of Pingtan Comprehensive Experimental Zone, a New Type of Sea Island City, Based on RSEI. Sustainability 2019, 12, 21. [CrossRef]

8. Andow, D.A.; Ruiz, G.M.; Carlton, J.T. Pathways-Based Risk Assessment of Exotic Species Invasions. In Invasive Species: Vectors and Management Strategies; Island Press: Washington, DC, USA, 2003; pp. 439-455. 
9. Weber, E.; Gut, D. Assessing the risk of potentially invasive plant species in central Europe. J. Nat. Conserv. 2004, 12, 171-179. [CrossRef]

10. Wittenberg, R.; Cock, M.J. Invasive Alien Species: A Toolkit of Best Prevention and Management Practices; CABI Publishing: Wallingford, UK, 2001.

11. Pisani, D.; Pazienza, P.; Perrino, E.V.; Caporale, D.; De Lucia, C. The Economic Valuation of Ecosystem Services of Biodiversity Componnts in Protected Areas: A Review for a Framework of Analysis for the Gargano National Park. Sustainability 2021, $13,11726$. [CrossRef]

12. Stinca, A.; Musarella, C.M.; Rosati, L.; Laface, V.L.A.; Licht, W.; Fanfarillo, E.; Wagensommer, R.P.; Galasso, G.; Fascetti, S.; Esposito, A.; et al. Italian Vascular Flora: New Findings, Updates and Exploration of Floristic Similarities between Regions. Diversity 2021, 13, 600. [CrossRef]

13. Zheng, J.M.; Zhang, J.L.; Zhao, D.M.; Bai, P.P.; Wu, D.C.; Deng, C.Y.; Zheng, Y.S. Seed plant flora of parks in Haitan Island, Fujian Province. J. Fujian Agric. For. Univ. (Nat. Sci. Ed.) 2018, 47, 587-592.

14. Zheng, X.X.; Zhang, Z.K.; Lin, H.Z.; Lin, X.; Wang, Q.; Huang, L.Q. Species Diversity Characteristics of Vegetation Communities in Different Succession Stages in Pingtan Island. For. Resour. Manag. 2019, 66-73.

15. Zhang, J.L.; Zheng, J.Z.; Wei, K.; He, Y.Q.; Shi, X.J.; Liu, J.X.; Deng, C.Y. Investigation and landscape application evaluation of wild native groundcover plant resources in Pingtan. Pratacultural Sci. 2019, 36, 368-381.

16. Huang, L.Q.; Zhang, Z.K.; Zheng, J.M.; Huang, S.J.; Lin, L.L.; Wang, Q.; Deng, C.Y.; Liu, X.Z. Functional Traits and Evolution Trend of Wild Plants in Continental Island: A Case Study of Pingtan Island. J. Trop. Subtrop. Bot. 2017, $25,429-437$.

17. Lewison, R.L.; Rudd, M.A.; Al-Hayek, W.; Baldwin, C.; Hines, E. How the DPSIR framework can be used for structuring problems and facilitating empirical research in coastal systems. Environ. Sci. Policy 2016, 56, 110-119. [CrossRef]

18. Andreu, J.; Vila, M. Risk analysis of potential invasive plants in Spain. J. Nat. Conserv. 2010, 18, 34-44. [CrossRef]

19. O'Toole, D.K. A risk assessment system for alien plant bio-invasion in Xiamen, China. J. Environ. Sci. 2008, 20,989-997.

20. Pheloung, P.C.; Williams, P.A.; Halloy, S.R. A weed risk assessment model for use as a biosecurity tool evaluating plant introductions. J. Environ. Sci. 1999, 57, 239-251. [CrossRef]

21. Editing Group of Flora of Fujian Province, Science and Technology Commission of Fujian Province. Flora of Fujian 1-6 Volumes; Fujian Science and Technology Press: Fujian, China, 1995.

22. Institute of Botany, CAS. Iplant. Available online: http:/ /www.iplant.cn/frps (accessed on 15 April 2020).

23. He, J.Q. Exotic Plants in China; Shanghai Scientific \& Technology Publishers: Shanghai, China, 2012.

24. $\mathrm{Wu}, \mathrm{Z}$.Y. The areal types of seed plant genera in China. Plant Divers. 1991, 13, 1-139.

25. Wu, Z.Y.; Zhou, Z.K.; Li, D.Z.; Peng, H.; Sun, H. The Areal-types of the World Families of Seed Plants. Plant Divers. 2003, 3, 245-257.

26. Notice on the Publication of the List of the First Invasive Alien Species in China. Available online: http://www.mee.gov.cn/ $\mathrm{gkml} / \mathrm{zj} / \mathrm{wj} / 200910 / \mathrm{t} 20091022$ 172155.htm (accessed on 16 April 2021).

27. Notice on the Publication of the List of the Second Invasive Alien Species in China. Available online: http://www.mee.gov.cn/ $\mathrm{gkml} / \mathrm{hbb} / \mathrm{bwj} / 201001 / \mathrm{t20100126 \_ 184831.htm} \mathrm{(accessed} \mathrm{on} 16$ April 2021).

28. Notice on the Publication of the List of the Third Invasive Alien Species in China. Available online: http://www.mee.gov.cn/ $\mathrm{gkml} / \mathrm{hbb} / \mathrm{bgg} / 201408 / \mathrm{t} 20140828$ 288367.htm (accessed on 16 April 2021).

29. Notice on the Publication of the List of the Fourth Invasive Alien Species in China. Available online: http://www.mee.gov.cn/ $\mathrm{gkml} / \mathrm{hbb} / \mathrm{bgg} / 201612 / \mathrm{t20161226 \_ 373636.htm} \mathrm{(accessed} \mathrm{on} 16$ April 2021).

30. National Key Management List of Invasive Alien Species (First Batch). Available online: http://www.moa.gov.cn/nybgb/2013 /dsanq/201712/t20171219_6119282.htm (accessed on 16 April 2021).

31. 100 of the World's Worst Invasive Alien Species. Available online: https://portals.iucn.org/library/sites/library/files/ documents/2000-126.pdf (accessed on 16 April 2021).

32. Bulleri, F.; Benedetti-Cecchi, L.; Jaklin, A.; Ivea, L. Linking disturbance and resistance to invasion via changes in biodiversity: A conceptual model and an experimental test on rocky reefs. Ecol. Evol. 2016, 6, 2010-2021. [CrossRef] [PubMed]

33. Li, Z.P.; Zhao, J.; Chen, Y.B.; Chen, H.; Lin, N.; Qiu, R.Z. Spatial variation and driving factors of invasive plants in Fujian Province, China. Chin. J. Appl. Ecol. 2019, 30, 2682-2690.

34. Gao, W.; Ye, G.F.; You, S.S.; Zheng, S.Q.; Han, M.M.; Du, L.H. Study on Status and Management Strategy of Invasive Alien Plants on Dongshan Island in Fujian. For. Resour. Manag. 2010, 45-50. Available online: http://www.lyzygl.com.cn/EN/Y2010/V0/I6/45 (accessed on 21 December 2021).

35. Peng, Z.B.; Jiang, Y.; Jiang, J.S. Risk evaluation indicator system for exotic plant invasion in Hainan Island, South China. Chin. J. Ecol. 2013, 32, 2029-2034.

36. Gooden, B.; French, K.; Turner, P.J.; Downey, P.O. Impact threshold for an alien plant invader, Lantana camara L., on native plant communities. Biol. Conserv. 2009, 142, 2631-2641. [CrossRef]

37. Thomas, S.E.; Evans, H.C.; Cortat, G.; Koutsidou, C.; Day, M.D.; Ellison, C.A. Assessment of the microcyclic rust Puccinia lantanae as a classical biological control agent of the pantropical weed Lantana camara. Biol. Control. 2021, 160, 104688. [CrossRef]

38. Berry, Z.C.; Wevill, K.; Curran, T.J. The invasive weed Lantana camara increases fire risk in dry rainforests by altering fuel beds. Weed Res. 2011, 51, 525-533. [CrossRef] 
39. Dhileepan, K.; Treviño, M.; Bayliss, D.; Saunders, M.; Shortus, M.; McCarthy, J.; Snow, E.L.; Walter, G.H. Introduction and establishment of Carvalhotingis visenda (Hemiptera: Tingidae) as a biological control agent for cat's claw creeper Macfadyena unguis-cati (Bignoniaceae) in Australia. Biol. Control. 2010, 55, 58-62. [CrossRef]

40. Dehnen, S.K.; Conroy, J. Working with gardeners to identify potential invasive ornamental garden plants: Testing a citizen science approach. Biol. Invasions 2018, 20, 3069-3077. [CrossRef]

41. Gari, S.R.; Newton, A.; Icely, J.D. A review of the application and evolution of the DPSIR framework with an emphasis on coastal social-ecological systems. Ocean Coast. Manag. 2015, 103, 63-77. [CrossRef] 